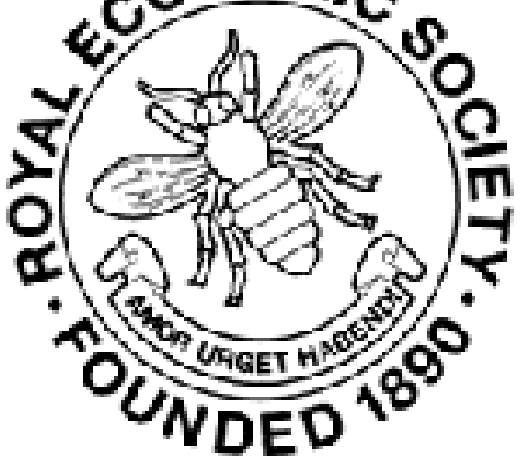

Bank Rate and the Money-Market in the United States

Author(s): J. E. Norton

Source: The Economic Journal, Vol. 31, No. 124 (Dec., 1921), pp. 482-495

Published by: Wiley on behalf of the Royal Economic Society

Stable URL: http://www.jstor.org/stable/2223078

Accessed: 27-06-2016 09:20 UTC

Your use of the JSTOR archive indicates your acceptance of the Terms \& Conditions of Use, available at

http://about.jstor.org/terms

JSTOR is a not-for-profit service that helps scholars, researchers, and students discover, use, and build upon a wide range of content in a trusted digital archive. We use information technology and tools to increase productivity and facilitate new forms of scholarship. For more information about JSTOR, please contact support@jstor.org.

Royal Economic Society, Wiley are collaborating with JSTOR to digitize, preserve and extend access to The Economic Journal 


\section{BANK RATE AND THE MONEY-MARKET IN THE UNITED STATES}

BANKING reform in the United States centred for long on proper control of the note issue. It was not till after the crisis of 1907 that the primary importance of issues of bank-credit was fully realised. ${ }^{1}$ The Federal Reserve Act of 1913 aimed at securing control of credit issues by an adaptation of the central banking system existing in various forms in Europe to the particular conditions prevailing in America. In Europe control is exercised mainly through the discount rate of the central bank in each country; a rise in this, when effective, produces a general rise in market rates, and this checks borrowing. The Federal Reserve Banks are expected to exert a similar control. ${ }^{2}$ Efforts to prevent.over-expansion of credit after the war were accompanied by much discussion as to how far this time-honoured device of raising the discount rate really secured the end desired, and the conclusion both in this country and in America seems to have been that it must, under existing conditions, be accompanied by other measures if credit was to be really restricted. This paper, however, is concerned not with the general question of how far a rise in market rates will limit credit-issues, but with the smaller problem of the effectiveness of the machinery provided under the Federal Reserve Act for securing such a rise. The system has not been working long enough for an appeal to experience to be very helpful; it was not in complete working order till 1917, and for the next three years the market was dominated by war-needs and Government finance. From the beginning of 1920 a policy of regulating credit was begun, ${ }^{3}$ but conditions

1 Cf. Laughlin, Banking Progress, ch. ii.

2 Cf. Report of the Flederal Reserve Board, 1914, p. 17. Cf. also "Address by P. M. Warburg," printed Federal Reserve Bulletin, 1916, p. 102 : "The aim of the system must therefore be to keep this gigantic structure of loans and investments both from over-contracting as well as from over-expanding," and A. C. Miller, American Economic Review, June 1921, p. 179 : "The regulation of the flow and volume of credit being in the last analysis the primary function of the Federal Reserve Banks."

3 Cf. A. C. Miller, American Economic Review, June 1921, p. 190 : "With the year 1920 the Federal Reserve Banks entered upon the exercise of their function of regulating credit in accordance with business and economic indications and under circumstances of extraordinary difficulty, and for the first time since the outbreak of the War, undertook to develop a policy of credit control by means of discount-rates." 
were still abnormal, and in any case a year and a half is too short a time on which to base definite conclusions. The method here adopted must therefore be an analysis of the machinery for regulation provided by the system with a view to making some estimate of its probable efficiency.

\section{I}

With regard to the function of increasing the supply of credit little need here be said. The capacity of the system to do this adequately depends on its controlling a sufficient quantity of resources in relation to the demands likely to be made upon it. The resources at its disposal have steadily increased since it was first instituted. ${ }^{1}$ As a result of steps taken in 1917 to centralise the gold supply, most of the gold in the country is now in the possession of the Federal Reserve Banks. ${ }^{2}$ It may be confidently affirmed that they are in a position to meet all seasonal increases in demand. With regard to such extreme demands as have arisen on exceptional occasions in the past, it is one of the objects of the new system to prevent such violent crises from arising, but even in the case of a panic there can be little doubt that it would be able materially to ease the situation.

The problem of securing a contraction of credit-issues or of preventing over-expansion is more difficult, and the machinery devoted to that end more complicated. The Federal Reserve Bank rate is intended to be used in the same way as European bank rates. We may now proceed to examine how it is designed to work and how far it is "effective" in the sense of controlling market-rates.

1. In the first place a word or two may be said as to the rate itself. There is in the Federal Reserve system no "official rate" as in England. The rate, or rather rates published by each Federal Reserve Bank are the actual rates at which they do business. Under the Act, the initiative in fixing rates rests with the banks subject to the approval of the Federal Reserve Board. In practice the determination of rates has been in the hands of the Board, the Banks simply accepting its suggestions. There is, further, no one set of rates for the whole country, local conditions determining them in each district, though the shifting

1 The total resources of the Federal Reserve Banks on May 25, $1921=$ $\$ 5,379,760,000$.

2 Cf. Federal Reserve Bulletin, 1917, p. 98. 
of funds by means of re-discounting between Federal Reserve Banks has done much to secure uniformity.

To be "effective" a rise in the Federal Reserve rate must be closely followed by a rise in the market rate. The machinery of the Federal Reserve Act is designed to secure such a correspondence. A brief description of this machinery may perhaps be given here. The reserves of all the banks belonging to the system must not be less than a certain legal fixed ratio to their demand deposits. Reserves to this amount must be kept at the Federal Reserve Banks. When the limit has been reached fresh deposits can only be taken when reserves are increased. Short of new gold deposits this can only be done by discounting with the Federal Reserve Banks such paper as they are allowed under the Act to discount. These re-discounts when placed to the credit of the discounting bank with the Federal Reserve Bank count as legal reserve, and fresh credit can be issued on that basis. The rate charged by the member bank for these issues will be determined by the rate which it has paid to the Federal Reserve Bank. In this way the rate at which Federal Reserve Banks re-discount affects the rate charged by member banks for discounting paper in the open market.

2. (a) Such is the connection established under the Act. The question now is, How does it work? In the first place there is the general difficulty of the lack of an organised discount market in the States. This has been due in the past mainly to absence of commercial paper suitable for discounting and, especially in New York, to the competition of the Stock Market for the available money. While on the one hand high call-loan rates may lead to a diversion of funds from the discount to the speculative market, high Federal Reserve rates, on the other, may have a similar effect. Bankers, knowing that commercial paper could only be re-discounted at a high rate, would tend to give up discounting and invest in call-loans instead. ${ }^{1}$ The result might be a check to the issue of commercial credit but an undesirable inflation of speculative credit-a proceeding which has been responsible for many of the New York money-market's difficulties in the past. Special steps are, however, being taken to develop the discount market by encouraging the use of forms of commercial paper suitable for re-discount purposes. In especial

1 Of. H. P. Willis, Magazine of Wall Street, May 28, 1921, p. 84 : "Interior banks have preferred ... to cut their re-discount obligations rather than to keep them up, and to use the funds held in consequence either in stock-market loans or advances on ineligible paper." 
the use of bankers' acceptances and the growth of the acceptance business is aimed at. ${ }^{1}$ The use of dollar exchange in foreign trade would have a similar effect. The competition of the call loan-market remains, however, formidable, particularly in New York. $^{2}$

(b) Apart from this question of the development of the market, the influence of the Federal Reserve rate will clearly depend on the extent to which banks do in fact re-discount, and this will depend on the relation of their reserves to their deposits. When the ratio between them approaches the legal ratio, money will be tight and market rates rise. When it is reached, further loans can only be made at a rate governed by the Federal Reserve rate. As in England, there are certain seasons in the year when the demand for money regularly increases, the ratio of reserves to deposits decreases, and the Federal Reserve Banks come automatically into control of the market. ${ }^{3}$ The periods of greatest demand are from mid-February to early April, from August 1st to October 1st, and the end of December. In addition to these, the collection of taxes at the end of each quarter produces a temporary withdrawal of funds from the market. It was intended that with the abolition of the Independent Treasury system, the Federal Reserve Banks should hold the Government deposits, and with this arrangement in force, these funds would be removed from the market until they were returned by the recipients of Government disbursements. But during the War, Government funds were deposited with all qualified national banks, and the total quantity so held is no less now than in 1914.4 Under these conditions, funds are

1 Cf. Report of the Federal Reserve Board, 1921, pp. 50, 382. Total acceptance liabilities of all member banks :-

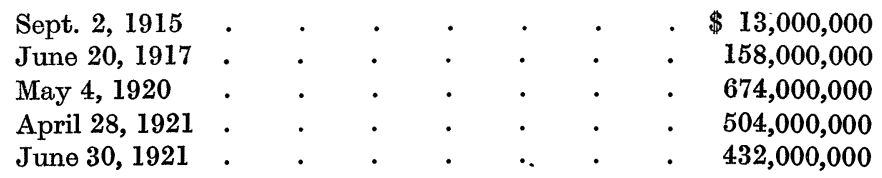

The drop between 1920 and 1921 is ascribed by many to the shrinkage in trade, not to any disinclination to use acceptances. Cf. Federal Reserve Bulletin, 1921, pp. 776, 1052.

2 Cf. Federal Reserve Bulletin, 1920, p. 370; Moulton, Financial Organisation, p. 645.

3 Cf. for this section Kemmerer, Seasonal Variations, National Monetary Commission Reports; Moulton, Financial Organisation, ch. xxiii.; Federal Reserve Bulletin, 1921, p. 777; Report of the Federal Reserve Board, 1919.

4 The total quantity of Government funds held outside the Federal Reserve Banks and their branches amounted in June 1920 to $\$ 313,997,973$. Of this sum $\$ 8,608,654$ were deposited abroad. 
returned to the market almost as soon as withdrawn. These deposits, it may be remarked, need not be kept within the legal ratio to reserves.

The next most important condition affecting the relation of the member banks to the Federal Reserve Banks is the normal size of their reserve. If it is habitually larger than the legal requirement, they will not tend to re-discount paper much, and the rate which they charge in the market will be little affected by the Federal Reserve rate. Further, if the ratio of reserve to deposits which bankers consider safe is above the legal ratio, they will tend to resort to the Federal Reserve Banks before the legal ratio is reached; if, on the other hand, their estimate is below this, they will be willing to expand their loans freely as long as that is legally possible. It follows that figures of excess reserves held are only really significant in relation to the reserve ratio habitually held. Conditions as regards reserves have been so abnormal since the Federal Reserve system came into operation, that little can be said as to the ratio which bankers in general consider safe at the present time. It has been estimated that the ratio of all demand deposits to money before the War never exceeded $8 \cdot 1$ per cent, ${ }^{1}$ and the general tendency is probably rather towards a too liberal than a too conservative estimate of the proper size of the credit structure relatively to its foundation.

Large imports of gold such as occurred in 1916 and have been occurring recently will tend to lessen the effectiveness of the Reserve rate. Thus the Board supported the removal of the embargo on gold exports in 1919 in the hope that the depletion of gold reserves would give them some control over the market. ${ }^{2}$ Where bank-rate is raised with the object of preventing an export of gold, as it used to be in England before the War, this state of affairs would not matter much. In America, where the rate is mainly needed as a check on the undue expansion of credit for speculative purposes, an expansion which is particularly likely to occur when gold reserves are increasing, the loosening of the connection with the Federal Reserve rate at such a time is likely to be especially dangerous.

The situation as regards reserves may be summed up as follows: if the banks know that they may shortly want to increase their reserves by re-discounting, they will tend to charge their customers a rate higher than the Federal Reserve rate;

1 Sprague, "Discount Policy of Federal Reserve Banks," American Economic Review, March 1921.

2 Cf. A. C. Miller, American Economic Review, June 1921, p. 182. 
otherwise, there will be a strong tendency to charge a lower one. The real condition of reserves may not be obvious at first sight, partly because, as already pointed out, the bankers' minimum may be different from the legal minimum, partly because reserves above the legal ratio may not be kept at the Federal Reserve Banks, but elsewhere. At present the greater part of the gold in the country is in their hands, but there seems no particular reason why this should always be so.

(c) In the next place, the control of the Federal Reserve Banks is weakened by the fact that not all the banks in the country are in the system. In June 1920 the aggregate resources of all the member banks $=\$ 32,194,301,000$, making 70 per cent. of the total banking resources of the country; the remaining 30 per cent. held by non-member banks amounted to $\$ 13,829,370,000 .{ }^{1}$ The existence of banks outside the system lessens control over the discount rate in two ways. In the first place, non-member banks are not bound by the legal minimum reserve, and can therefore expand credit to any extent that they see fit. Secondly, Federal Reserve notes which do not count as legal reserve for member banks can be used by non-member banks for reserve purposes. The system thus increases their power to extend credit without exercising any corresponding check on them.

(d) This brings us to a further peculiarity of American banking which makes the bank rate there less directly effective than it is in Europe. Increased loans from the Bank of England, for instance, mostly go directly to swell the available funds in the money-market. Increased re-discounts by the Federal Reserve Banks are generally used to increase reserves on which further loans are based. It follows that though re-discounting will oblige a member bank to raise the rate at which it makes its own loans, this rise will only be proportionate to the rate at which it has itself borrowed and not equal to or above it. ${ }^{2}$ A rise in the Federal Reserve rate will have to be very high in order to produce a moderate rise in the market-rate, the exact relation between the two depending on the amount of fresh loan credit which the bank bases on its borrowed reserve. The official theory now appears to be that the Federal Reserve rate will be so high that resort will only be had to it in times of pressure. ${ }^{3}$ It has been found in practice, however, that Federal Reserve resources have been used as a basis for profitable operations by

1 Report of the Federal Reserve Board, 1920.

2 Cf. Reed, Journal of Political Economy, January 1921.

3 Report of the Federal Reserve Board, 1919, pp. 2, 67. 
member banks. ${ }^{1}$ An Act was passed in April 1920 providing for the application of extra high rates at Federal Reserve Banks to specially heavy borrowers. ${ }^{2}$

(e) In England, the connection, not by itself a very close one, between the bank rate and the market rate is made closer by the fact that the banks adjust their deposit rates in relation to movements in the bank rate. This adjustment is purely the result of custom. In 1918 a similar link was established between bankdeposit rates and the Federal Reserve rates. Competition between banks for deposits appeared likely to push up the interest allowed on them; following on a letter from the Governor of the Federal Reserve Board in February, pointing out the inconvenience of a general rise in rates at that time, an agreement was made between the clearing-house banks of New York in March to fix the maximum rate for deposits in relation to the New York Federal Reserve Banks' rate on 90-day commercial paper. ${ }^{3}$ In July the Chicago banks adopted the same system, and further efforts to fix deposit rates were made in August. In 1920, however, the Board itself objected to this arrangement as hampering it in fixing discount rates, ${ }^{4}$ and on January 16 , after a meeting of bankers held at Washington to discuss the question, the New York Clearing House Association fixed a maximum rate for deposits of $2 \frac{1}{4}$ per cent., and similar action was recommended at Chicago. ${ }^{5}$ Any such link is therefore for the present nonexistent.

There is one connection between the market and Reserve Banks which may be expected to become more important as time goes on. In England a rise in the bank rate acts mainly through its effect on the bill-brokers who are obliged, when money is short, to borrow their working capital from the Bank of England, and who fix their discount-rates to correspond. The American money-market is less specialised, and the part played by separate discounting institutions smaller, but traces of a similar process

1 Federal Reserve Bulletin, 1918, p. 1169; 1920, p. 558.

2 Cf. Report of the Federal Reserve Board, 1920, p. 2.

3 The exact arrangement was an advance of $\frac{1}{4}$ of 1 per cent. in interest rate for every advance of $\frac{1}{2}$ of 1 per cent. in the Reserve Banks' rate up to a maximum of 3 per cent. in the interest rate. Cf. Federal Reserve Bulletin, 1918, p. 252.

- Federal Reserve Bulletin, 1920, p. 3: "The Board wishes to be free to approve such discount-rates as conditions may make necessary or desirable, but it is anxious at the same time to avoid a disturbance of the whole banking system such as would most likely result from an advance in the interest rates allowed on out-of-town balances."

5 For this paragraph cf. Fiederal Reserve Bulletin, 1918, pp. 160, 252, 806; 1920, p. 117. 
have been observed there. The advance in rates in 1920 had, according to the Federal Reserve Bulletin (1920, p. 345), "an unexpected effect" in shortening loans from commercial paperbrokers. As the discount-market develops the rôle of paperbroking is likely to become more important and the effect of their operations on the market greater. This would provide a direct link between the market rate and the Federal Reserve rate, and its sensitiveness to changes in the latter would then be correspondingly greater.

On the whole, however, it appears that the direct connection is only an uncertain one. As Professor Willis says, "the rate itself has only a minor influence upon current market rates except when it is considered as part of a broad general policy." 1 Its failure was demonstrated during the period May 1920-May 1921. "It has, of course, been obvious that the high rates which have been charged in some quarters have not been due to the policy of the Federal Reserve Banks, particularly as such high rates have frequently been asked by institutions which were in no way dependent on Federal Reserve Banks for accommodation, while, on the other hand, not a few which have been largely accommodated have seen fit in some cases to continue their old rates to customers, who were thus carried at a charge which was distinctly less than that of the Federal Reserve Banks themselves." 2 Steps will therefore have, as a rule, to be taken to make a rise in the Reserve rate effective.

\section{II}

When the Bank of England ceased to be the principal discounter of bills in the London money-market, and special measures had to be taken to make its rate effective, it was on operations in the open market that it chiefly relied. Provision was made for enabling the Federal Reserve Banks to reinforce the raising of their rates in a similar way. "It was the intention of the Federal Reserve Act," says Professor Willis, " to provide a means whereby the banks could make their rates effective." 3 Under the Act they are empowered to buy and sell gold, United States paper, cable transfers, bankers' acceptances, and such commercial paper as is eligible for re-discount. Such transactions enable them to affect market rates directly, giving them control not only

1 H. P. Willis, Magazine of Wall Street, May 28, 1921, p. 84.

${ }^{2}$ F'ederal Reserve Bulletin, July 1921, p. 775.

3 H. P. Willis, American Banking, p. 325. 
over member banks, but over non-member banks as well. This is indeed sometimes regarded as the chief means by which control is to be exerted. "If this function (of carrying on open-market transactions) were not . . . exercised, the making of the discount rate effective would be entirely dependent upon the extent to which member banks chose to obtain re-discounts from the Federal Reserve Banks. With the power on the part of the Federal Reserve Banks to go into the open market, the control of the prevailing interest rate is always in the hands of the Federal Reserve Banks if they have a substantial amount of loan funds at their disposal." 1 The extent of their power depends on how large a quantity of resources they can employ in such transactions. The following tables show the resources at different dates of the Federal Reserve Banks and of all other banks in the United States, and the relative resources of Federal Reserve and member banks at different centres in April 1921.

\section{TABLE I.}

Total Resources.

(In thousands of dollars.)

Federal Reserve Banks.

All other Banks.

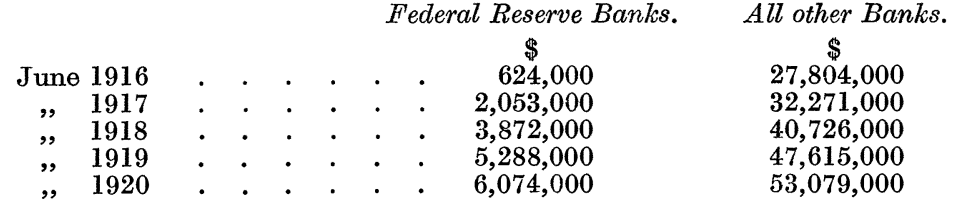

TABLE II.

Total Resources (April, 1921).

$\begin{array}{ccc}\text { 1. Federal Reserve 2. All member banles } & \text { 3. Percentage o } \\ \text { Banks. } & \text { in the district. } & 1 \text { to } 2 .\end{array}$

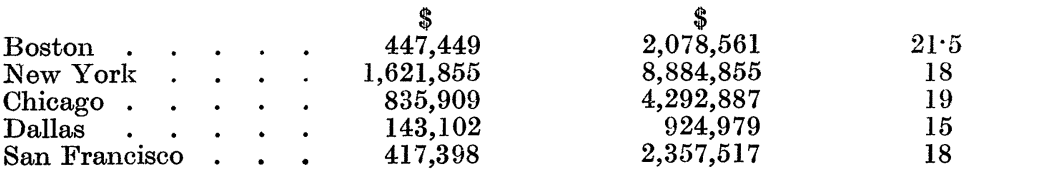

Their power in this direction is to some extent checked by the limitation on the kinds of paper they may buy, and on the amount of acceptances which any one bank may hold. In this

1 H. P. Willis, American Banking, p. 171. Cf. also "Address by Mr. P. M. Warburg," printed Federal Reserve Bulletin, 1916, p. 102. "In order effectively to develop their operations, Federal Reserve Banks cannot depend upon the borrowing requirements of their member banks alone, ... the first year's experience has already shown that they must look largely to open market operations . . . in order to secure their share of business and influence." 
connection the development of the acceptance business is particularly important, since bankers' acceptances are specially suitable for their operations. ${ }^{1}$

These open-market transactions enable the Federal Reserve Banks to control rates by increasing or lessening their sales and purchases as occasion may demand. ${ }^{2}$ By buying less or selling their holdings at low prices they will tend to raise market-rates. They will be most active in the market at times when money is tight and it is desirable to increase loanable funds. But if this is to be successful, the banks must be continually carrying on business in the buying and selling of paper in normal times, ${ }^{3}$ and this is not compatible with the theory referred to on page 67 , that the Federal Reserve rates should as a rule be higher than market rates. ${ }^{4}$

It has been suggested that another possible method of control lies in the regulation of the note-issue. ${ }^{5}$ If the amount of fiduciary notes is limited, the demand for other kinds of cash will be increased. This will tend to deplete the legal reserves of the banks and so force them to increase their re-discounts or to limit their loans. In practice raising Reserve rates has been accompanied by direct suggestion and exhortation on the part of the Board and by the adoption of "rationing" credit, attempted discrimination between essential and non-essential loans and special high rates for heavy borrowers. ${ }^{6}$

The following chart shows the movement of discount and call rates in the New York market, together with the discount rate of the New York Federal Reserve Bank from November 1914 to June 1921.

The history of the rates is briefly as follows:-During the period November 1914 to November 1916 the reserves of the banks were very large, and the legal reserve requirement had just

1 Cf. Warburg, Federal Reserve Bulletin, 1916, p. 102 : " Their most important field in this respect is the banker's acceptance." For the development of the acceptance market, cf. the table given on p. 66 .

2 Warburg, Federal Reserve Bulletin, 1916, p. 102.

3 Cf. Report of the Federal Reserve Board, 1914, p. 18: "To influence the market, a Reserve Bank must always be in the market."

4 Cf. Federal Reserve Bulletin, 1917, p. 76 : "In view of the fact that the rate for bankers' acceptances recently maintained by the Federal Reserve Banks has been somewhat higher than the open-market rate, the holdings of acceptances by the Federal Reserve Banks have been materially reduced during the past weeks."

5 A. C. Miller, "Federal Reserve Policy," American Economic Review, June 1921.

${ }^{6}$ Cf. Federal Reserve Bulletin, 1918, p. 1169; 1920, pp. 118, 456, 558; Report of the Federal Reserve Board, 1920; 1921, p. 58 . 
been lowered; the full legal reserves had not yet been entirely transferred to the Federal Reserve Banks ; consequently there was

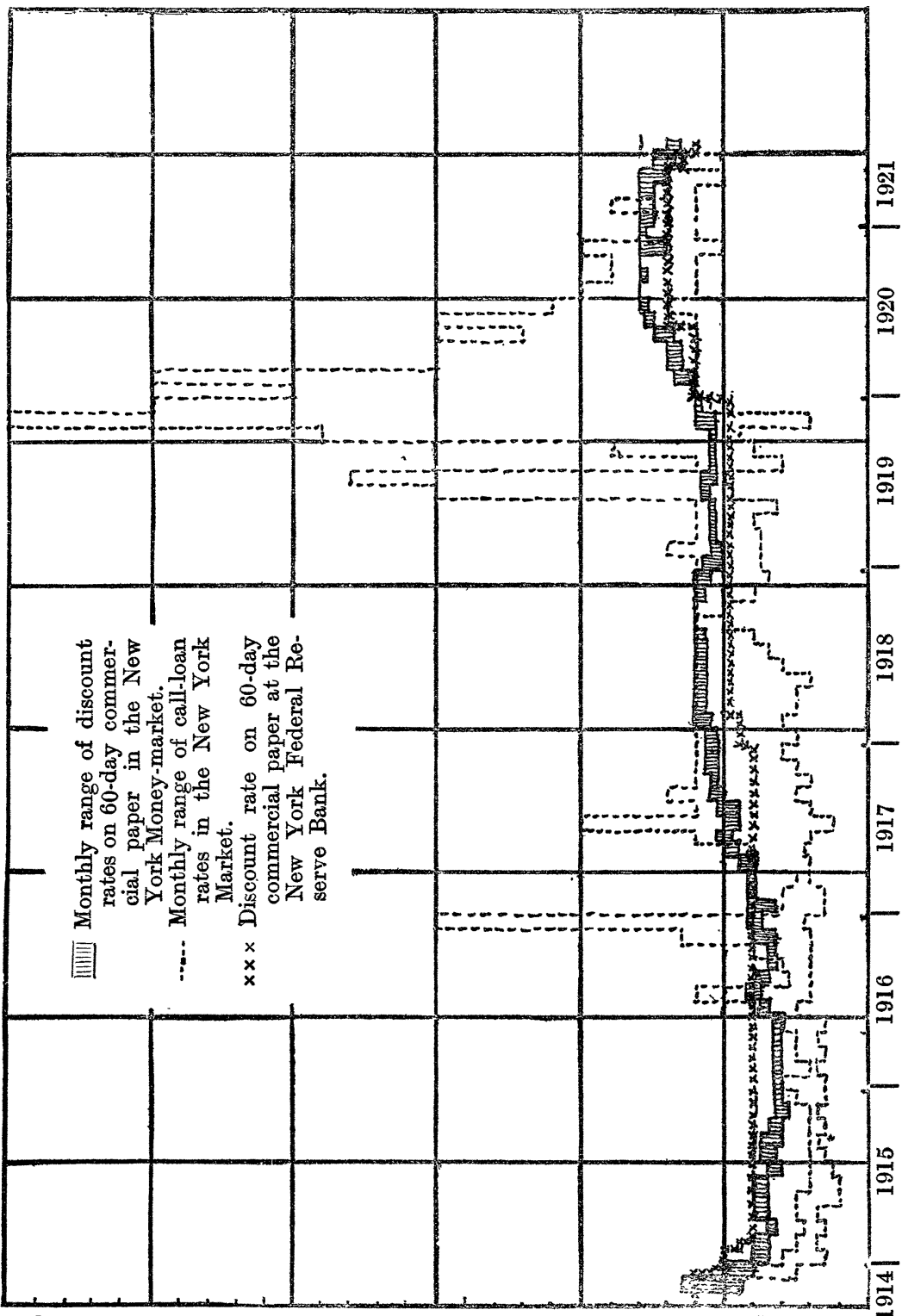

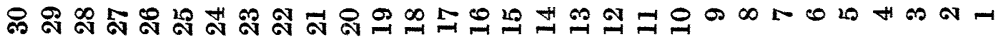

little re-discounting, market rates were low and the Federal Reserve rate had practically no influence. By the end of 1916 the process of transferring reserves was completed, and the immense demand for capital pushed market rates up to the 
Federal Reserve rate. During the period when the United States were in the War, the financial policy pursued was to keep the Federal Reserve rate low in order to enable the banks to discount Government paper cheaply. This state of affairs continued during 1919. In January 1920 and again in June, the Federal Reserve rate was raised, but in both cases the rise in market rates preceded it. 1 It cannot be said that changes in the Federal Reserve rate have so far done anything in the way of anticipating or hurrying on a change in market rates. ${ }^{2}$

A table of the re-discount and open-market operations of the New York Federal Reserve Bank and of all the Federal Reserve Banks 1920-21 is appended.

TABLE III.

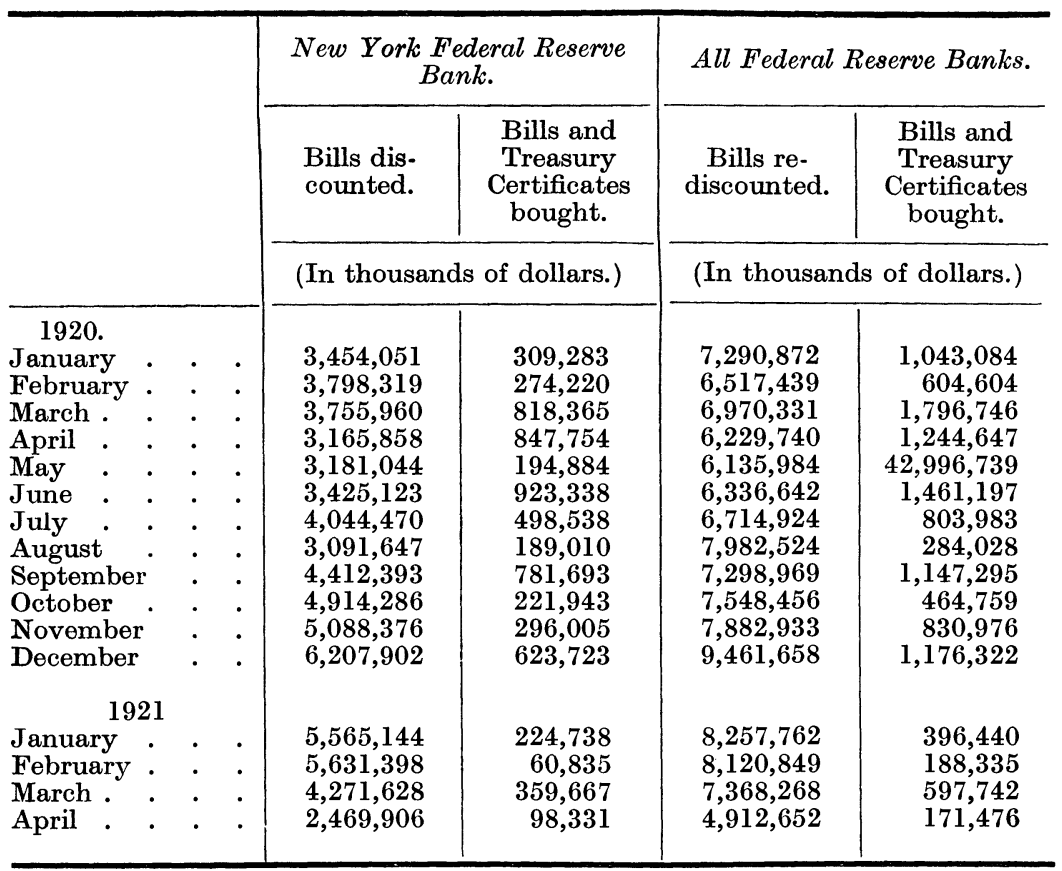

\section{III}

Apart from the actual machinery provided under the Act, there are certain other conditions affecting the situation which may be grouped together here.

1 Cf. Report of the Federal Reserve Board, 1921, p. 381.

${ }^{2}$ Cf. W. P. G. Harding in the Federal Reserve Bulletin for August 1921, p. 895 sqq.

No. 124.-VOL. XXXI. 
For one thing, bank reserves in America are not so sensitive to changes in credit as they were, for instance, in England before the War. ${ }^{1}$ The system of fiduciary note issue is such that an expansion of credit is less directly followed by a depletion of reserves than here. The disorganised state of international trade has, at the present time, the same effect, and in any case, unless New York develops a large international short-loan business, the effect on reserves through foreign Exchange channels will always be less immediate than in London. Scientific opinion in the United States is moving towards the adoption of some other criterion than the reserve ratios for regulating credit, such as the movement of prices, ${ }^{2}$ but the business public are still actuated by a belief in the old test. It follows that it may be difficult to secure support for a general rise in discount rates unless the reserve ratio is visibly affected, even though credit conditions may make it advisable. In the next place, opposition to a rise in Reserve Bank rates may be more strongly roused than in England owing to the fact that here it affects first, and most directly, the billbrokers, who are less powerful and organised than the banks. In America, where re-discounting by the banks is much more frequent, the impact falls directly on them and will be more immediately felt. Further, there is considerable suspicion of the Federal Reserve Banks as being in some way backed by the State, and jealousy of their competition might make extensive market operations difficult. On the other hand, as the success of the system and the real advantages resulting from it become more and more recognised, it is acquiring a prestige which will give to its advice and to its actions an influence making such difficulties as have been considered much less important.

The problem of securing effective control over market rates is more complicated than it is in England, and it is at a different stage of development. Here the device of raising the bank rate worked best when the Bank of England was the largest institution in the market, and the other banks were small and not very numerous. The difficulty now is that the bank is confronted by a very few, very powerful banks. In America, on the other hand, the attempt at central control has to face a very large number of banks over an immensely diversified area, some large and powerful, others small and inefficient. Organised co-

1 Cf. A. C. Miller, American Economic Review, June 1921, pp. 192-196; Federal Reserve Bulletin, 1919, p. 911.

${ }^{2}$ Cf. Sprague, "Discount Policy of the Federal Reserve Banks," American Eiconomic Review, March 1921. Also Reed, "The Work of the Federal Reserve Board," Journal of Political Economy, Jan. 1921. 
operation between the central authorities and the other banks, which is one solution for the English situation, is, for good or ill, much more difficult to secure in the latter case. As regards existing arrangements, the Federal Reserve rate by itself is not likely to be effective at all times. The use of operations in the open market to enforce it has not yet reached full development, but with the growth in the resources of the Federal Reserve Banks, and with increased organisation of the discount market, these will become more important, and it is on them that chief reliance will probably be placed in the future.

J. E. Norton 